\title{
Description of a new species of Leuserattus Prószyński et Deeleman- Reinhold, 2012, with comments on the type species L. gunung Prószyński et Deeleman-Reinhold, 2012 and associated genera (Araneae: Salticidae)
}

\author{
Описание нового вида Leuserattus Prószyński et Deeleman- \\ Reinhold, 2012, с замечаниями о типовом виде L. gunung \\ Prószyński et Deeleman-Reinhold, 2012 и связанных родах \\ (Araneae: Salticidae)
}

\author{
Christa L. Deeleman-Reinhold ${ }^{1 *}$, Jeremy A. Miller ${ }^{2}$ \\ Христа $\Lambda$. Аилеман-РейнхольА ${ }^{1 *}$, Алкереми А. Миялер ${ }^{2}$
}

\footnotetext{
'Sparrenlaan 8,4641 GA Ossendrecht, The Netherlands. E-mail: cdeeleman@planet.nl

${ }^{2}$ Naturalis Biodiversity Center, Postbus 9517, 2300 RA Leiden, The Netherlands. E-mail: jeremy.miller@naturalis.nl

* Corresponding author
}

KEY WORDS: Aranei, canopy fogging, jumping spiders, Southeast Asia, taxonomy, tropical rainforest.

КЛЮЧЕВЫЕ СЛОВА: Aranei, окуривание крон леса, пауки-скакунчики, Юго-Восточная Азия, таксономия, тропический дождевой лес.

ABSTRACT. Leuserattus gunung Prószyński et Deeleman-Reinhold, 2012, the type species of a monotypic genus, is redescribed in the light of new morphological data. The known distribution of this species is extended from Sumatra to Java, Indonesia. A second species - Leuserattus pristinus sp.n. ( $\left.\sigma^{7}+\right)$ from the canopy rainforest of Borneo - is diagnosed and described. The new species is distinct from L. gunung by the body colour pattern, cheliceral armament, and the conformation of copulatory organs in both sexes. A close relationship of the genus Maileus with Leuserattus is suggested; relationships with Saaristattus Logunov et Azarkina, 2008 and Muziris Thorell, 1878 are discussed. The epigyne of the type specimen of Maileus fuscus Peckham et Peckham, 1907 is illustrated.

How to cite this paper: Deeleman-Reinhold C.L., Miller J.A. 2021. Description of a new species of Leuserattus Prószyński et Deeleman-Reinhold, 2012, with comments on the type species L. gunung Prószyñski et Deeleman-Reinhold, 2012 and associated genera (Araneae: Salticidae) // Arthropoda Selecta. Vol.30. No.1. P.105-112. doi: 10.15298/arthsel.30.1.09

PEЗЮME. Leuserattus gunung Prószyński et Deeleman-Reinhold, 2012, типовой вид монотипического рода, переописан в свете новых морфологических данных. Известное распространение вида расширено от Суматры до Явы, Индонезия. Из полога дождевого леса Борнео описан и диагностирован второй вид - Leuserattus pristinus sp.n. ( $\left.\bigcirc^{7}+\right)$. Новый вид отличается от L. gunung окраской тела, вооружением хелицер и структурой копулятивных органов у обоих полов. Предполагается близкое родство рода Maileus и Leuserattus; обсуждаются родственные связи с родами Saaristattus Logunov et Azarkina, 2008 и Muziris Thorell, 1878. Проиллюстрирована эпигина типового вида Maileus fuscus Peckham et Peckham, 1907.

\section{Introduction}

The monotypic genus Leuserattus Prószyński et Deeleman-Reinhold, 2012 was erected for an alleged euophryine spider species $\left(\sigma^{7}+\right)$ from North Sumatra. Maddison [2015] preliminarily placed it in the euophryines but considered a possible relationship with the nannenines as well. The suprageneric taxonomy, however, is not the focus of the present paper. Re-examination of the type material of $L$. gunung lead to a more detailed analysis of the structure of the internal female copulatory organs. The suggestion [Prószyński, Deeleman, 2012: 42] of the association to Saaristattus tropicus Logunov et Azarkina, 2008 was found to be unjustified. Arguments are provided below in the relationships section.

In the years 1992-2009, a long-term ecological survey of arthropods was carried out by Andreas Floren (Biozentrum der Universität Würzburg, Germany) in the rainforest canopy of Sabah, Borneo using the fogging method. The target of that project was to establish the effects of forest degradation on the arthropod fauna in the canopy. All spiders (several thousands) were made available to us, comprising more than 800 morphospecies in 32 families [Floren, Deele- 

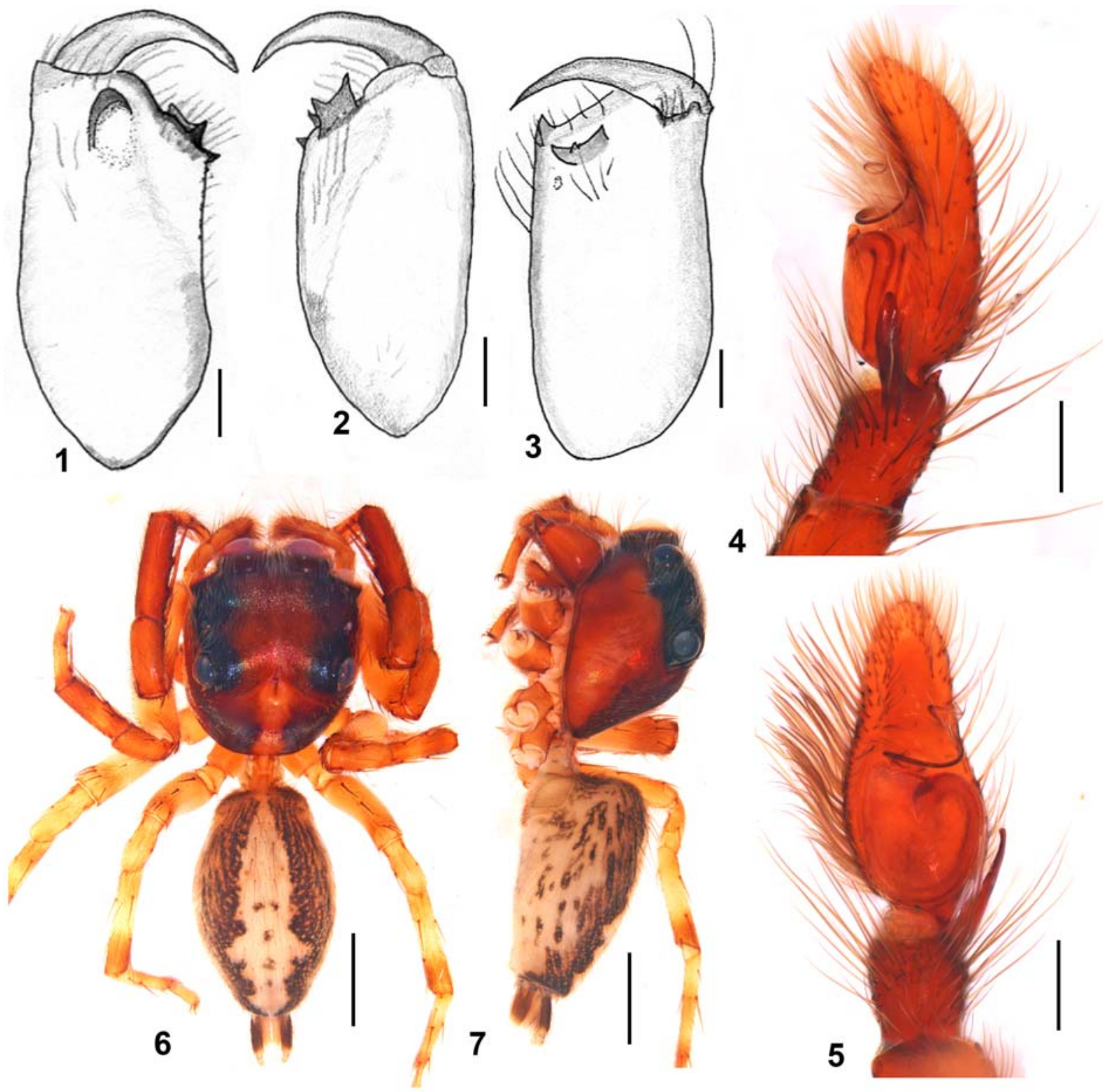

Figs 1-7. Leuserattus gunung Prószyński et Deeleman-Reinhold, 2012 (1, 2, 4, 5, holotype $\sigma^{7}, 6$, 7, paratype 9$)$ and L. pristinus sp.n. (3, holotype $\mathrm{O}^{\mathrm{T}}$ ): 1 - left chelicera, dorsal view; 2, 3- same, ventral view; 4 - left male palp, retrolateral view; 5 - same, ventral view; 6 - female habitus, dorsal view; 7 - same, lateral view. Scale bars: (6-7) $1 \mathrm{~mm},(1-5) 0.2 \mathrm{~mm}$.

Рис. 1-7. Leuserattus gunung Prószyński et Deeleman-Reinhold, $2012(1,2,4,5$, голотип О7, 6, 7, паратип +) и L. pristinus sp.n. (3, голотип О $): 1$ - левая хелицера, вид сверху; 2, 3 - тоже, вид снизу; 4 - левая пальпа самца, вид ретролатерально; 5 - тоже, вид снизу; 6 - гаитус самки, вид сверху; 7 - тоже, вид сбоку. Масштаб: (6-7) 1 мм, (1-5) 0,2 мм.

man-Reinhold, 2005]. This collection is very important to increase our knowledge of the Malay Archipelago, an area and habitat that remains underexplored. We have discovered males and females of a second species of Leuserattus. The new species was limited to Poring Hot Springs, a lowland primary rainforest within the Mount Kinabalu area.

The aims of the present paper are (1) to redefine and redescribe the type species of Leuserattus by adding new data on the vulva structure, (2) to introduce and describe a second species $\left(\sigma^{7}+\right)$, and (3) to discuss genus' relationships with Saaristattus Logunov et Azarkina, 2008, Muziris Thorell, 1878 and Maileus Peckham et Peckham, 1907.

\section{Material and methods}

Epigynes were dissected and cleared in clove oil for several hours before drawing. The material was examined with stereomicroscope Zeiss Stemi SV11. Drawings were made with a Zeiss drawing tube. Photographs were made with a Nikon DS-Ri1 camera mounted on a Leitz M165 C 
stereomicroscope. Extended focus images were composited with Auto-Montage software version 5.03. All material listed here is deposited in the Naturalis Biodiversity Center, Leiden (the former Rijksmuseum van Natuurlijke Historie, RMNH; curator: J.A. Miller).

Abbreviations used in the text are as follows: cd copulatory duct, fc - first coil of copulatory duct, PLE posterior lateral eyes, RTA - retrolateral tibial apophysis. Measurements are given in $\mathrm{mm}$ and obtained by using an ocular micrometer. Body lengths exclude protruding eye lenses and spinnerets; leg length is measured on the dorsal side: total (femur + patella + tibia + metatarsus + tarsus).

\section{Systematics}

\section{Leuserattus Prószyński et Deeleman-Reinhold, 2012}

Type species: L. gunung Prószyński et Deeleman-Reinhold, 2012: 42, figs 78-85 ( $\left.{ }^{7}+\right)$; by monotypy.

DESCRIPTION. Medium-sized fissidentate spiders (Figs 1-3). Carapace high, with steep thorax decline directly behind PLEs (Fig. 7), with a pale central band contrasting with dark colour of carapace. In L. gunung, the central band is thinner than in L. pristinus (cf. Figs 6 and 15). Chelicerae parallel, not slender, with one or two promarginal teeth; the male of the type species bears a specific projection on the dorsal surface near the base of the fang (Fig. 1), absent in the new species; both species have a broad bidentate retromarginal tooth (Figs 2, 3). Legs are relatively short, in males and females buff with light brown rings on femur, tibia and metatarsus, in males of both species tibia I is almost black, with ventral black brush, in females tibia I is brown. Tibia I and II with three pairs of strong ventral spines, metatarsus with two pairs ventrally. Abdomen somewhat longer than carapace. The male palpal bulb structure is deviant from any other genus and not compatible with euophryines; in the tegulum the retrolateral branch of the sperm duct lacks the characteristic S or C-like loop, instead it runs a thin semicircle all around the edge of the tegulum (Figs 5, 17). The epigyne of Leuserattus consists of a translucent sheet covering the whole width and length of the epigyne, with no visible median septum; the sheet bears one or more pairs of concentric spiraling ridges guiding the embolus; in the centre of the spirals the ridges abruptly switch and through a sharp bend continue as a markedly sclerotized copulatory duct running one or several coils (Fig. 10: cd) directed perpendicularly dorsad; the first coil, prominent in ventral view of the epigyne (Figs 11, 12, 18: fc) might be interpreted as a copulatory opening. The large spermathecae lie dorso-posterior on the vulva and are thickwalled and bean- or pear-shaped, anteriorly excavated (L. gunung; Fig. 12) or tapering (L. pristinus; Fig. 25).

RELATIONSHIPS. In the 2012 paper [Prószyński, Deeleman, 2012], the epigyne of Saaristattus tropicus Logunov et Azarkina, 2008 was illustrated in fig. 86 next to that of L. gunung in fig. 84 in order to emphasize the similarity of the patterns of circular concentric spiraling ridges. The alleged similarity of the female copulatory organs of Leuserattus with that of Saaristattus Logunov et Azarkina, 2008 [Prószyński, Deeleman-Reinhold, 2012: 42] is misleading. No account has been given on the basically different copulatory ducts and spermathecae in Saaristattus and Leuserattus, which in the former genus are shaped as a single long tube. The vulval structure in $L$. gunung was correctly described in the original description [Ibid., 2012:
42, figs 84-86]: a small part of the copulatory ducts and voluminous thick-walled spermathecae are partly visible in fig. 85 but omitted in fig. 86 . Yet, fig. 85 failed to show the underlying coils of the copulatory ducts because they are hidden from view. Males of the type species of the two genera have widely different palps. Later, the genus Saaristattus was moved to the new tribe Tisanibini [Maddison, 2015].

On the other hand, male palp in the genus Muziris Thorell, 1878 is superficially similar to that of Leuserattus. The male of Muziris doleschalli Thorell, 1878 [Prószyński, 1984: fig. 86] has a palp in which the embolus is somewhat like that of L. pristinus, however the bulb is shaped differently, with the sperm duct barely visible in the complex tegulum, and unlike the structure unique for Leuserattus with the smooth oval tegulum. Moreover, the palpal tibia in Muziris is extraordinarily elongated. No image of the Muziris female exists; all we know of the epigynal conformation in that the genus can be found in the original description of the type species M. doleschallii [Thorell, 1878: 230]: “...vulva ex fovea parva levi sub-transversa constat, quae costa tenui longitudinali in duas divisa est." (vulva consists of a small smooth subtransverse depression divided in two halves by a thin longitudinal ridge); i.e., the median septum presents in the latter species but absent from Leuserattus.

Two sketches of the epigyne of the type specimen of Maileus fuscus Peckham et Peckham, 1907 deposited in the Museum of Comparative Zoology, Harvard College (USA) are available. One (Fig. 26) was made by Marek Żabka (Siedlce, Poland) and published by Prószyński [2017: fig. 36G], the other (Fig. 27) was made by the senior author (CD) around 1983. Both sketches suggest a close similarity of the epigyne of M. fuscus to that of Leuserattus, viz., the median septum is absent, instead some concentric spirals in the transparent sheet and a central small dark coil are shared in both these genera. In Leuserattus, the dark coil represents the first coil after the sharp bend from the surface spirals into the copulatory duct and could indeed be considered to be the first coil of that duct. Somatic characters of M. fuscus, as described by Peckham \& Peckham [1907: 612, o only], conform to those of Leuserattus females, viz. the carapace shape, eye quadrangle and cheliceral shape and teeth. Colour pattern of carapace: "cephalothorax dark on the sides, brown in the middle" [Peckham, Peckham, 1907: 612]. In the type specimen body colouration is completely faded. In the Leuserattus species, a dark carapace includes a central longitudinal pale area, extending right onto the posterior margin. "Abdomen dorsally with central longitudinal scalloped white band and upper sides mottled brown, lower sides white, spotted with brown" and "legs pale with dark rings"; both these features are also seen in L. gunung females (Figs 6, 7). Leg decoration and spination of anterior tibiae and metatarsi and leg formula (IV $>$ III $>I>I I$ in females) also agree. This still does not justify considering Leuserattus a junior synonym of Maileus without a closer examination of the type specimen of M. fuscus and its vulva. A molecular analysis and/or a discovery of the male of $M$. fuscus would confirm or deny a synonymy of these genera.

\section{Leuserattus gunung Prószyński et Deeleman-Reinhold, 2012}

Figs 1-2, 4-13.

TYPES. HOLOTYPE $O^{7}$ (RMNH, ARA.18266), INDONESIA, Sumatra, Gunung Leuser N.P., Bohorok $\left(3^{\circ} 33^{\prime} \mathrm{N}, 98^{\circ} 08^{\prime} \mathrm{E}\right)$, primary dipterocarp forest, 200-300 m a.s.1., hand collecting, 11.06.1983, P.R. \& C.L. Deeleman. PARATYPES (all specimens from the type 

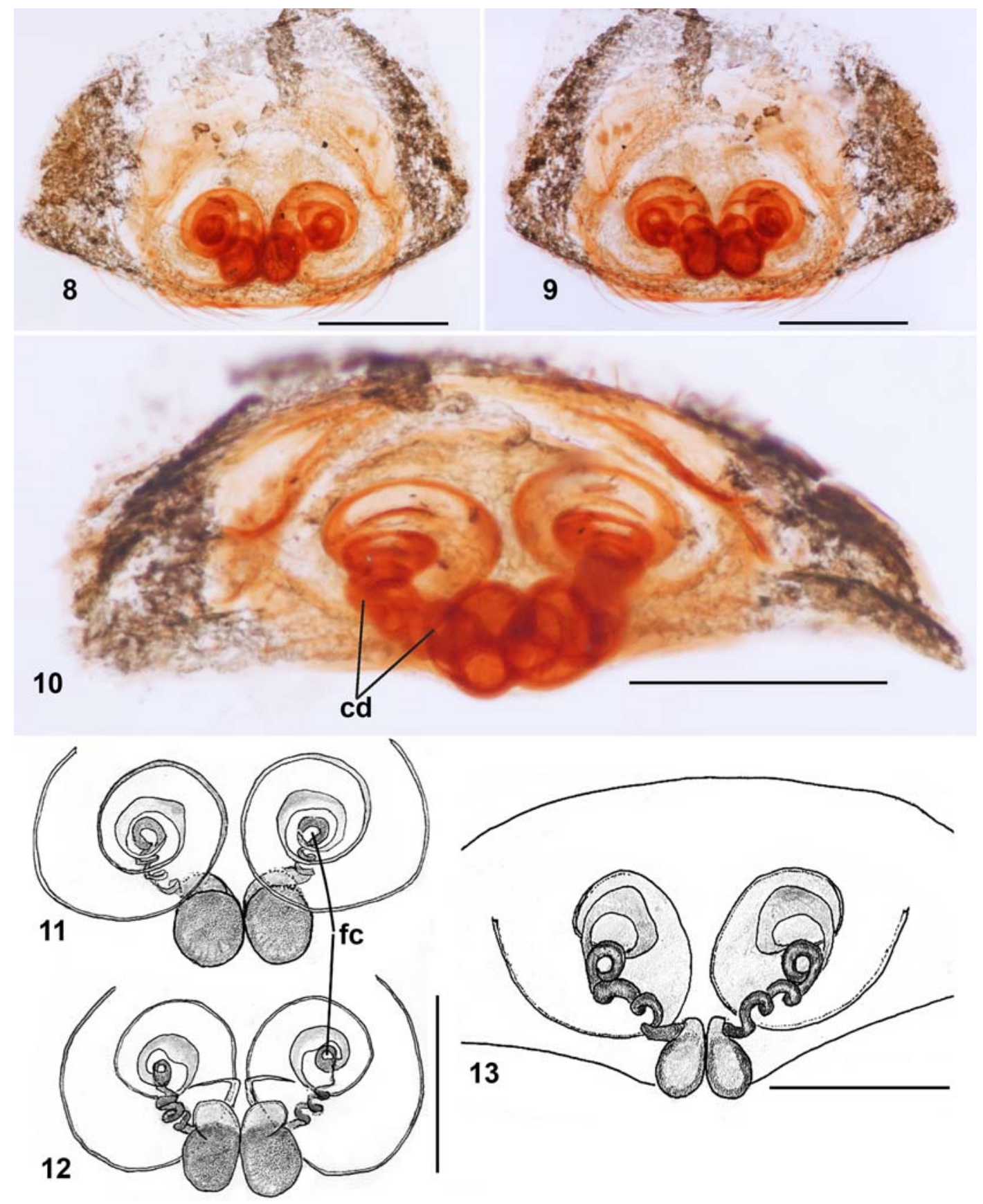

Figs 8-13. Leuserattus gunung Prószyński et Deeleman-Reinhold, 2012, cleared vulva of paratype $9: 8,11$ - ventral view; 9, 12 dorsal view; 10, 13 - anterior view. Abbreviations: $\mathrm{cd}$ - copulatory duct, fc - first coil of copulatory duct. Scale bars: $0.2 \mathrm{~mm}$.

Рис. 8-13. Leuserattus gunung Prószyński et Deeleman-Reinhold, 2012, осветленная вульва паратипа +: 8, 11 — вид внизу; 9, 12 вид сверху; 10, 13 - вид спереди. Сокращения: cd — копулятивный проток, fc — первая петля копулятивного протока. Масштаб: 0,2 мм.

locality): 1 (RMNH, ARA.18267), 18.02.1983, P.R. Deeleman \& S. Djojosudharmo; 1 \& (RMNH, ARA. 18268), 15.11.1983, S. Djososudharmo; 1 + (RMNH, ARA.18269), bamboo, 15.09.1983, S. Djojosudharmo; 1 + (RMNH, ARA.18270; drawn by J. Prószyñski), trail 2, foliage, 9.03.1983, S. Djojosudharmo; 1 क (RMHN, ARA.18271), trail 3, from foliage, 13.09.1983, S. Djojosudharmo; 2 우 (RMHN, ARA.18272), from foliage 16.02.1983; 1 subadult 9 (RMNH, ARA.18273), 2.05.1984, P.R. Deeleman; 1 $(\mathrm{RMNH}$, ARA.18291), trail 3, 29.04.1983, S. Djojosudharmo.
OTHER MATERIAL. SUMATRA: $1 \uparrow$ (RMNH.ARA.18275), Gunung Leuser N.P., Ketambe ( $\left.3^{\circ} 40^{\prime} \mathrm{N}, 97^{\circ} 39^{\prime} \mathrm{E}\right)$, dipterocarp rainforest (now destroyed by logging), leaf litter, 15.04.1985, S. Djojosudharmo. - JAVA: 1 क (RNHH.ARA.18276), Ujung Kulon Reserve $\left(6^{\circ} 44^{\prime} \mathrm{S}, 107^{\circ} 1^{\prime} \mathrm{E}\right)$, primary forest, leaf litter, 19-25.11.1986, S. Djojosudharmo.

ADDITIONS TO THE DESCRIPTION. MALE (holotype). Measurements. Body length 4.80, carapace 2.25 long, 2.10 wide, 1.60 high (from PER perpendicularly down). 


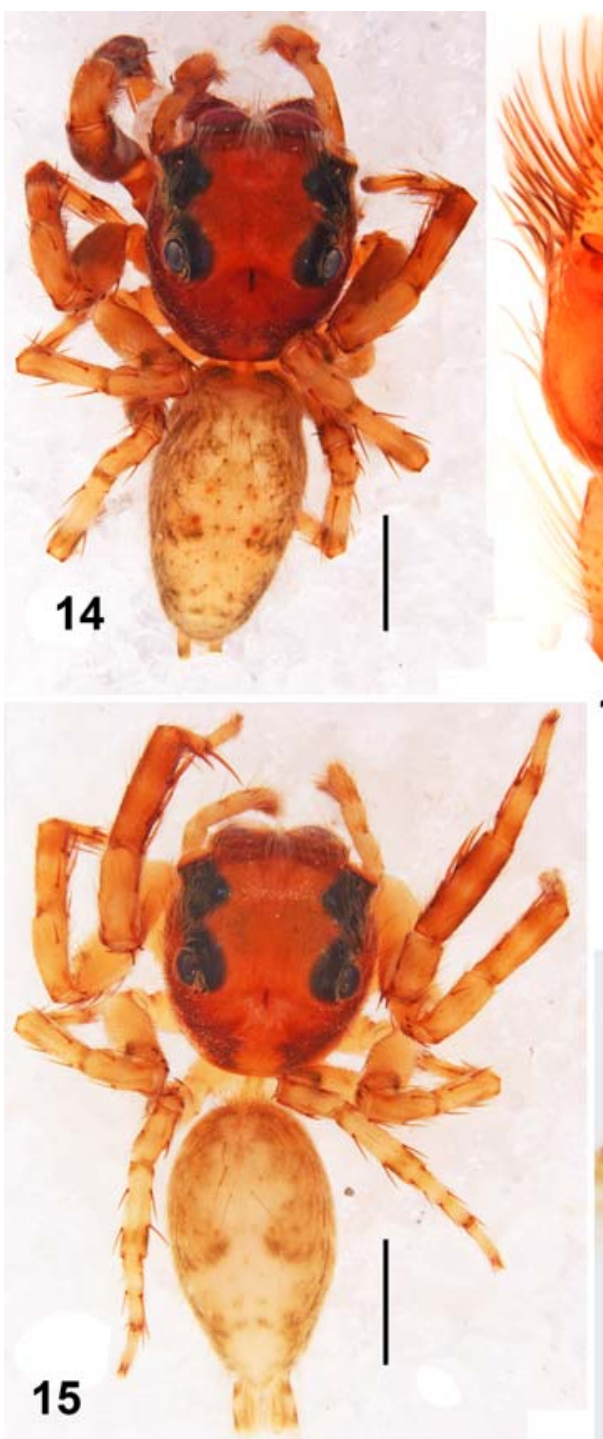

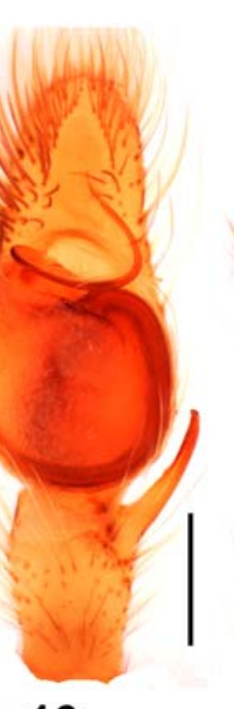

16
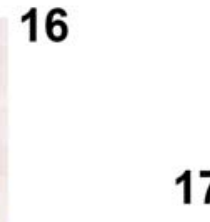

20

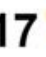

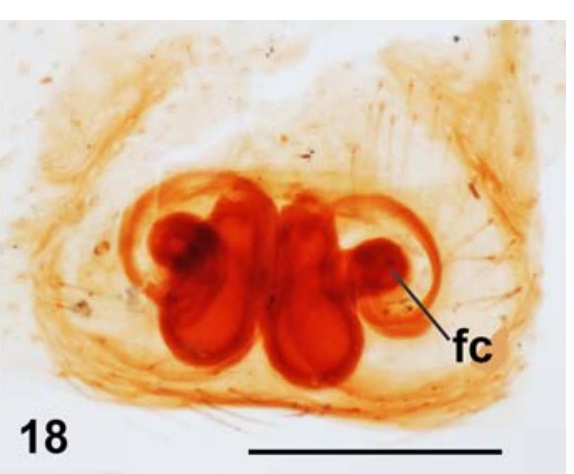

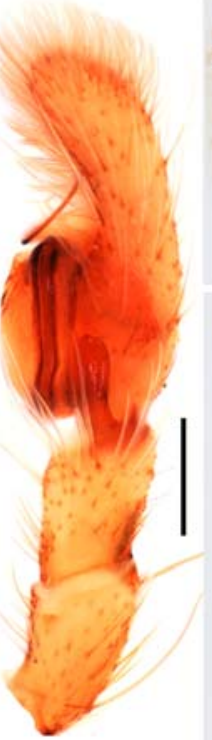

19

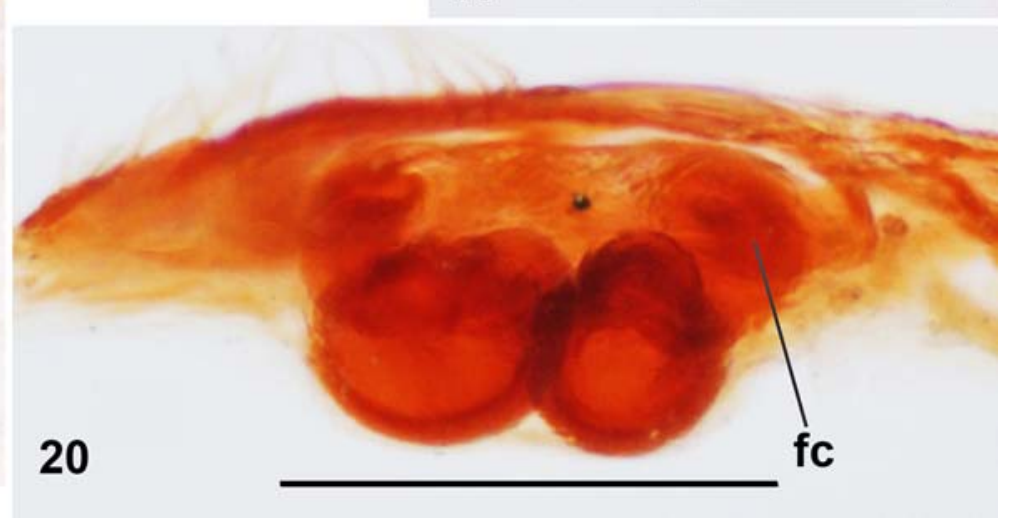

Figs 14-20. Leuserattus pristinus sp.n., holotype $\sigma^{7}(14,16-17)$, paratype 9 (15, 18-20): 14, 15 — habitus, dorsal view; 16 - left male palp, ventral view; 17 - same, retrolateral view; 18 - cleared vulva, ventral view; $19-$ same, dorsal view; $20-$ same, anterior view. Scale bars: $(14,15) 1 \mathrm{~mm},(16-20) 0.2 \mathrm{~mm}$.

Рис. 14-20. Leuserattus pristinus sp.n., голотип ○ (14, 16-17), паратип ㅇ (15, 18-20): 14, 15 — габитус, вид сверху; 16 - левая пальпа самца, вид снизу; 17 - тоже, вид сбоку-сзади; 18 - осветелнная эпигина, вид внизу; 19 - тоже, вид сверху; 20 - тоже, вид спереди. Масштаб: $(14,15) 1$ мм, (16-20) 0,2 мм.

Chelicerae 1.00 long, 0.55 wide, abdomen 2.45 long. Length of leg segments: I $5.45(1.75+0.90+1.40+0.90+0.50)$; II $4.55(1.60+0.75+1.10+0.65+0.45) ;$ III $5.25(1.80+0.75$ $+0.95+1.20+0.55)$; IV femur 1.80 , remaining segments lost. Leg formula: I $>$ III $>$ II (IV incomplete). Coloration. Carapace [Prószyñski, Deeleman, 2012: figs 78, 79] dark chestnut with buff median band which abruptly narrows in the posterior margin zone which along with the sides below eye region are covered with short white hair. Chelicerae anteriorly with a rounded apophysis framing a depression near the base of the fang; promargin with one smaller and one larger tooth, retromargin with a large bidentate tooth (Figs 1,2). Legs predominantly brown, femur IV partly buff, leg I dark brown, patella and tibia I with black ventral brush. Abdomen as in female (Fig. 6). Palps as shown in Figs 4, 5: RTA long and flattened, slightly curved, distal fifth of length tapering, dorsally with small pointed subtooth tilted upward (Fig 4); tegulum proximally rounded, lacking tegular lobe, outer edge encircled by a thin sperm duct which is distally connected to embolus by a dorsal haematodocha; embolus consisting of a wide transverse basal semicoil, and terminating with a small $360^{\circ}$ coil distally (Fig. 5).

FEMALE (paratype, habitus Figs 6, 7). Measurements. Body length 5.00, carapace 2.40 long, 2.00 wide, 1.40 high, abdomen 2.40 long. Length of leg segments: I $4.75(1.50+$ $0.80+1.15+0.80+0.50) ;$ II $4.35(1.60+0.70+1.00+0.60+$ $0.45)$; III $5.30(1.75+0.70+1.10+1.20+0.55)$; IV 5.00 $(1.60+0.65+1.00+1.20+0.55)$. Leg formula: III $>$ IV $>$ I $>$ II Coloration. Carapace pattern (Fig. 6) as in the male. Chelicera differs from that in males in absence of anterior rounded apophysis and two promarginal teeth of equal size. Legs pale buff with pale brown rings, patella and tibia in leg I 

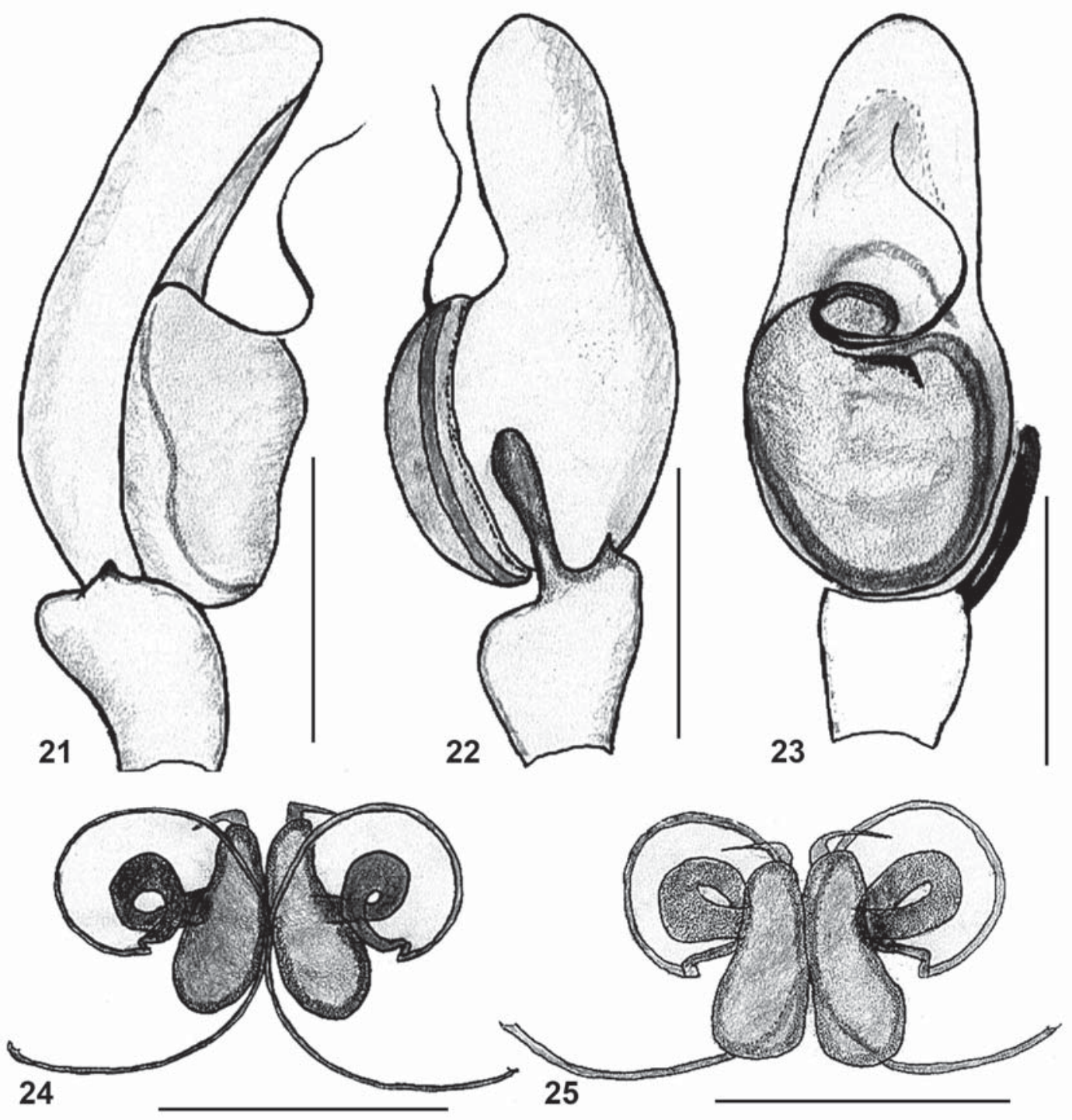

Figs 21-25. Leuserattus pristinus sp.n., left palp of holotype $O^{7}$ (21-23), cleared epigyne of paratype + (24-25): 21 - prolateral view; 22 - retrolateral view; 23, 24 - ventral view; 25 - dorsal view. Scale bar: $0.2 \mathrm{~mm}$.

Рис. 21-25. Leuserattus pristinus sp.n., Левая пальпа голотипа О7 (21-23), осветленная эпигина паратипа + (24-25): 21 — вид спереди-сбоку; 22 - вид сзади-сбоку; 23, 24 - вид снизу; 25 - вид сверху. Масштаб: 0,2 мм.

somewhat darkened. Abdomen pattern as in the male, central white band wider, margins in posterior part meandering. Epigyne as in Figs 8-13 (see above under the genus definition): translucent sheet with on either side two concentric spirals; the copulatory duct consists of one larger and several small coils (Fig. 10: cd); spermathecae thick-walled, beanshaped, distally bipartite.

DISTRIBUTION. Indonesia: North Sumatra (Gunung Leuser), W. Java.

HABITAT. Primary lowland dipterocarp rainforest.

\section{Leuserattus pristinus sp.n.}

Figs 3, 14-25.

TYPES. HOLOTYPE $O^{7}$ (RMNH, ARA.18278), MALAYSIA, Borneo, Sabah, Kinabalu area, Poring Hot Springs $\left(6^{\circ} 2^{\prime} \mathrm{N}, 116^{\circ}\right.$ $\left.41^{\prime} \mathrm{E}\right)$, primary rainforest, $600-620 \mathrm{~m}$ a.s.l., fogging canopy of
Aporosa lagenocarpa (Phyllanthaceae, formerly Euphorbiaceae), Loc 1-2, treecode A168, 26.02.1996, A. Floren. PARATYPES (all collected by A. Floren): 1 ( RMNH, ARA.18279), $10^{7}, 8$ 우, (RMNH, ARA.18277), together with the holotype; 2 O+, (RMNH, ARA.18288), same data, fogging Aporosa sp., daytime, Loc 6, treecode Al7, fog 3, 27.02.1996; $1 \mathrm{O}^{\top}, 3$ 우, (RMNH, ARA.118282), same data, fogging Aporosa subcaudata, Loc 12, treecode As38, 21.02.1996; $2 \sigma^{7} \sigma^{7}, 1$ +, 2 immatures (RMNH, ARA.118284), same data, fogging Aporosa subcaudata, treecode As40, 8.10.1996; 1 + (RMNH, ARA.18289), same data, Loc 7, treecode Al3, fogging Aporosa lagenocarpa, refog after 3 years, 24.03.1996; $2 O^{7} O^{7}, 5$ oㅇ, 2 subadults (RMNH, ARA.118286), same data, fogging Aporosa subcaudata, Loc 14, treecode As52, fog 6, refog after 3 years, 19.02.1996; 1 (RMNH, ARA.118285), same data, Loc 9, treecode As11, refog after 3 years; 1 ( (RMNH, ARA.118285), same data; $2 \sigma^{7} \sigma^{7}, 1$ q (RMNH, ARA.18280), same data, fogging Barringtonia scortechinii, Barringtoniaceae, 1998.3 treecode Bs81, 27.03.1998; 1 ( (RMNH, ARA.18283), same data, fogging Ficus leptogrammus, Moracaeae, treecode F189 fog11, 29.02.1998; 2 우우 
(RMNH, ARA.118287), same data, fogging Ochanostachys amentatea, Olacaceae, 1998 fog 1+2, treecode Oa80, 27.03.1998.

ETYMOLOGY. The species epithet is derived from the Latin adjective pristinus meaning 'pure, genuine': i.e., an inhabitant of primary forest.

DIAGNOSIS. Both sexes of the new species can be distinguished from L. gunung by the wider central pale carapace band, and by differences in abdomen pattern (Figs $6,7,14,15)$. Male chelicerae lack the rounded projection with a depression anteriorly found in L. gunung. Palps: RTA is distinct from that in gunung by being distally flattened like a spoon; the dorsal subtooth is similar, erect but not tilted. The embolus in L. gunung runs one basal wide semicoil, in L. pristinus also, covering almost the full cymbial width; however the distal part is almost straight (Figs 16, 17, 23 ) in contrast to a small full circle distally in L. gunung (Figs 4, 5). In the epigyne, the cd is much shorter and runs only one full spiral on the surface instead of two in $L$. gunung; the spermathecae are pear-shaped (Figs 18-20, 24, 25).

DESCRIPTION. MALE (holotype). Measurements. Body length 5.60, carapace 2.50 long, 2.00 wide, 1.60 high. Chelicerae 1.25 long, 0.60 wide, abdomen 3.05 long, 1.55 wide. Length of leg segments: I $5.75(1.60+1.00+1.55+1.10+$ $0.50) ;$ II $4.70(1.45+0.70+1.15+0.75+0.65) ;$ III 5.35 $(1.90+0.75+1.10+1.00+0.60) ;$ IV $4.85(1.50+0.75+$ $1.10+0.90+0.60)$. Leg formula: I $>$ III $>$ IV $>$ II. Carapace dark, central part pale chestnut, central band on the posterior slope not clearly defined and well separate from round white patch near the rear margin (Fig. 14) with short white hair. Chelicerae (Fig. 3) with a large promarginal tooth, a retromarginal tooth with broad, shallow excavation with central denticle (Fig. 3). Legs similar to those of L. gunung, with pale brown rings and very dark tibiae I in males, with dark ventral brush. Abdomen anterior part with irregular grey spots, posteriorly chevron-like as an interrupted transverse bar, in darker specimens there is a second transverse uninterrupted dark bar. Palps as in Figs 16, 17, 21-23: embolus runs a basal semicircle over nearly the full cymbial width followed by an almost straight distal part.

FEMALE. Measurements. Body length 4.20, carapace 2.00 long, 1.60 wide, 1.20 high, abdomen 2.20 long, 1.40 wide. Length of leg segments: I $3.95(1.30+0.70+0.95+$ $0.60+0.40)$; III $3.85(1.50+0.50+0.85+0.60+0.40) ;$ III $4.15(1.60+0.60+0.75+0.80+0.30) ;$ IV $4.25(1.50+$ $0.50+0.80+0.90+0.55)$. Leg formula: IV $>$ III $>$ I $>$ II. Carapace as the male except that the central light area is continuous with the white patch on the rear margin as in L. gunung (Fig. 15). Chelicerae as in the male, except for two strong promarginal teeth. Legs as in the male, except for tibia I paler and without a ventral brush. Abdomen darker than in the male, anterior half dark with a contrasting central broad white bar in the middle with dark central line. Epigyne as in Figs 18-20, 24, 25: only one paired spiral (Fig. 18-20); copulatory ducts short with one dark coil only (Fig. 18: fc); spermathecae large, elongate and pear-shaped.

DISTRIBUTION. Malayaan Borneo, Sabah: Poring Hot Springs (Kinabalu).

HABITAT. Found only in canopy samples from primary rainforest at $610-690 \mathrm{~m}$ a.s.1., not present in ground collecting.

Acknowledgements. We are grateful to Dmitri Logunov (Manchester, UK) for his valuable comments on the earlier draft of the manuscript. The anonymous referee is thanked for critical comments helping much to improve the manu-
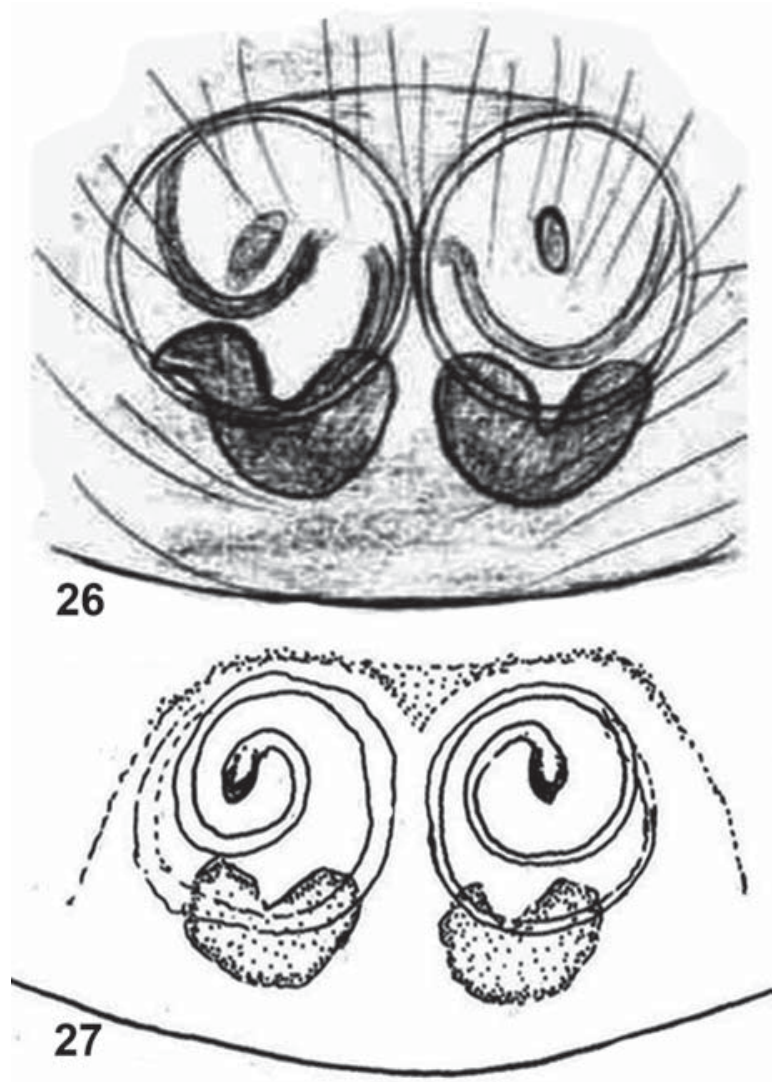

Figs 26-27. Maileus fuscus Peckham et Peckham, 1907, holotype + $: 26$ - sketch of epigyne by M. Żabka in Prószyński [2017]; 27 - sketch of epigyne by C.L. Deeleman-Reinhold, 1983.

Рис. 26-27. Maileus fuscus Peckham et Peckham, 1907, голотип +: 26 - рисунок эпигины М. Żabka, из Prószyński [2017]; 27 - рисунок эпигины C.L. Deeleman-Reinhold, 1983.

script. Andreas Floren confided us all spider material of his canopy fogging arthropods project in North Borneo. This enabled us to discover a huge unexpected spider fauna, basically different from that collected in traditional ways on the ground. The late Otto Kraus provided special drawing paper which proved to be most useful. We are very grateful to Julia Deeleman and Koen Merkens for helping us with some illustrations.

\section{References}

Floren A., Deeleman-Reinhold C.L. 2005. Diversity of arboreal spiders in primary and disturbed tropical forests // Journal of Arachnology. Vol.33. No.2. P.323-333.

Logunov D.V., Azarkina G.N. 2008. Two new genera and species of Euophryinae (Aranei: Salticidae) from SE Asia // Arthropoda Selecta. Vol.17. No.1-2. P.111-115.

Maddison W.P. 2015. A phylogenetic classification of jumping spiders (Araneae: Salticidae) // Journal of Arachnology. Vol.43. No.3. P.231-292.

Peckham G., Peckham E.G. 1907. The Attidae of Borneo // Transactions of the Wisconsin Academy of Sciences, Arts and Letters. Vol.15. No.2. P.603-653.

Prószyński J. 1984. Atlas rysunków diagnostycznych mniej znanych Salticidae (Araneae // Zeszyty Naukowe Wyższej Szkoły Rolniczo-Pedagogicznej w Siedlcach. Vol.2. P.1-177. 
Prószyński J. 2017. Pragmatic classification of the world's Salticidae (Araneae) // Ecologica Montenegrina Vol.12. P.1-133

Prószyński J., Deeleman-Reinhold C.L. 2012. Description of some Salticidae (Aranei) from the Malay archipelago. II. Salticidae of Java and Sumatra, with comments on related species // Arthropoda Selecta. Vol.21. No.1. P.29-60.
Thorell T. 1878. Studi sui ragni Malesi e Papuani. II. Ragni di Amboina raccolti Prof. O. Beccari // Annali del Museo Civico di Storia Naturale di Genova. Vol 13. P.1-317.

WSC 2020. World Spider Catalog. Natural History Museum Bern, online at http://wsc.nmbe.ch, version 21.0. (accessed 22 June 2020).

Responsible editor D.V. Logunov 